\title{
O MUINDO DOS PEQUENOS NA ÓRBITA DOS ADULTOS
}

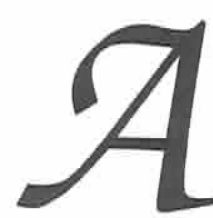

pós alguns anos do início do êxodo dos brasileiros, é hora de perguntarnos o que se passa com as crianças e adolescentes filhos dessa migração. Primeiramente, é preciso constatar as distintas e por vezes múltiplas situações por eles vivenciadas: há os que participam do processo migratório presenciando a partida dos pais: há os que partem e acabam ficando: há os que vão e acabam voltando; há os que nascem no exterior e por lá permanecem e, ainda, há os filhos do exterior que são trazidos para a terra dos pais.

Sem dúvida, existe um emaranhado de fios que se cruzam e descruzam, em meio a vantagens e desvantagens, riscos e possibilidades. Vidas precoces envoltas na lógica complexa do grande circuito da mobilidade, mas que guardam algumas especificidades. tais como as explicitadas ao longo dos textos aqui apresentados: "(...) Certo dia minha mãe me chamou para conversar, pensei que era (sic) alguma coisa que eu tinha feito no colégio, na rua, ou até em casa, mas não, era para falar que a gente ia mudar de casa e também de país ". "O pai falou que a gente tinha que ir, e eu não queria ir".

Além da migração poder soar como algo inesperado elou indesejado, uma vez desencadeada, suscitará questões atinentes ao relacionamento entre pais e filhos, aos desafios do processo educativo envolvendo a familia e a escola; além de suscitar problemas quanto à própria constituição de uma identidade do jovem e adolescente.

Em torno disso gravitam cinco textos: Sidnei traz o depoimento de alguém que foi para o Japão, ingressou na escola japonesa e depois retornou ao Brasil, enquanto os pais lá permanecem (sem conseguir a almejada poupança para o retorno). Ushi analisa os filhos dos brasileiros no Japão, que criados "à la brasileira", acabam, na verdade, nem sendo brasileiros e muito menos japoneses. Kyoko, também ela a partir da migração BrasilJapão, estuda as crianças que ficaram aqui, as que do Japão vêm ao Brasil e as que permanecem no Japão, apontando para cada caso os aspectos que mais requerem atenção. Igor e Alexandra valem-se do fluxo de Governador Valadares para Portugal e centram suas atenções sobre as crianças que permanecem do lado de cá da viagem a partir do ponto de vista delas mesmas e do ponto de vista dos adultos. Bianka dá voz a um grupo de adolescentes que vivem em Barcelona.

Em todos os casos acima mencionados, vale destacar a aguçada percepção que as crianças e/ ou adolescentes demonstram em relação ao fator decisivo da migração dos pais - o trabalho -, o qual é encarado de forma ambivalente: por um lado é o fator que lhes possibilita ter o que não teriam sem a migração dos pais; por outro, é o mesmo trabalho, sempre excessivo, que rouba a companhia dos mesmos (tanto para os que permanecem no Brasil, quanto para os que se encontram no destino "junto" a eles). Não conseguem. porém, explicitar o que Ushi e Kyoko antevêem (para o caso específico dos que permanecem no Japão), que aos filhos da migração está reservado o mesmo destino dos pais: ser mãode-obra barata para o capital.

Dois outros textos, de Súlvio et al. e de Ernesto. voltam-se para os filhos da migração no Brasil, caracterizando-se, ambos, pela novidade que trazem: o primeiro, por traçar um paralelo, no âmbito da migração interna, entre jovens migrantes e os da chamada "segunda geração"; o segundo, por abordar as relações no interior da família chinesa.

\section{Dirceu Cutti}




\section{TRAVESSIA - NÚMEROS PUBLICADOS}

01 - Sazonais

02 - Cidade

03 - Fronteira Agrícola

04 - Violência

05 - Voto

06 - Barragens

07 - Cultura

08 - Trabalho

09 - Família

10 - Religião e Religiosidades

11 - Estrangeiros

12 - Educação

13 - Pena de Morte

14 - Migrar e Morar

15 - Tempo e Espaço

16 - Desemprego e Subemprego

17 - Imagens

18 - Novas Tecnologias

19 - Identidades

20 - Saúde

21 - Emigração
22 - Retorno

23 - Metrópole

24 - Índios e Territórios

25 - Deslocamentos Compulsórios

\& Restrições à Migração

26 - Mulher Migrante

27 - Nomadismos

28 - Meio Ambiente

29 - Albergue

30 - Clandestinidade

31 - Festas

32 - Memória

33 - Mercosul

34 - Associações

35 - Gerações na Migração

$\mathrm{N}^{\circ}$ Especial - O Retorno (Sayad)

36 - Um Olhar Retrospectivo

37 - Refugiados

38 - Bairros e Vizinhanças

39 - Assentamentos

40 - Redes
41 - Migração Laboral

42 - Linguagens e Símbolos

43 - Imprensa \& Literatura

44 - Etnias

45 - Mobilidade \& Flexibilidade

46 - Sagrado

47 - Cotidiano

48 - Fronteiras

49 - Narrativas

50 - Políticas Públicas

51 - Preconceitos

52 - Legado de Scalabrini

53 - Implicações Psicológicas

54 - Espaço Urbano

55 - Brasileiros no Exterior

56 - Alteridades

57 - Acolhida \& Hospitalidade Bíblia e Pastoral

58 - Acolhida \& Hospitalidade

Cultura e Sociedade

59 - Filhos da Migração

\section{É possível montar a coleção e adquirir números avulsos*}

(* Números 8,10 e 12 só disponíveis para coleção)

\section{Forma de Pagamento}

Depósito nominal à Pia Soc. dos Miss. de S. Carlos; Bradesco; Ag. Tabatinguera n ${ }^{\circ} 0515-0 ; c^{\circ} n^{o}$ 23083-9 com envio de cópia do comprovante ou Cheque nominal à Pia Soc. dos Miss. de S. Carlos.

\section{Valor da Assinatura}

() Ass. válida por 1 ano

$\mathrm{R} \$ 20,00$

( ) Ass. válida por 2 anos.

$\mathrm{R} \$ 30,00$

( ) Ass. válida por 3 anos

$\mathrm{R} \$ 40,00$

() Exterior (1 ano)

U\$ 20,00

Rua Vasco Pereira, 55 Liberdade CEP: 01514-030 São Paulo/SP - Brasil

Fone/Fax: (0xx11)3208.6227

cemsp@uol.com.br www.cemsp.com.br 